\title{
Wound healing treatment by high frequency ultrasound, microcurrent, and combined therapy modifies the immune response in rats
}

\author{
Raciele I. G. Korelo ${ }^{1}$, Marcelo Kryczyk ${ }^{2}$, Carolina Garcia ${ }^{2}$, \\ Katya Naliwaiko ${ }^{3}$, Luiz C. Fernandes ${ }^{4}$
}

\begin{abstract}
Background: Therapeutic high-frequency ultrasound, microcurrent, and a combination of the two have been used as potential interventions in the soft tissue healing process, but little is known about their effect on the immune system. Objective: To evaluate the effects of therapeutic high frequency ultrasound, microcurrent, and the combined therapy of the two on the size of the wound area, peritoneal macrophage function, $\mathrm{CD} 4^{+}$and $\mathrm{CD} 8^{+}, \mathrm{T}$ lymphocyte populations, and plasma concentration of interleukins (ILs). Method: Sixty-five Wistar rats were randomized into five groups, as follows: uninjured control (C, group 1), lesion and no treatment (L, group 2), lesion treated with ultrasound (LU, group 3), lesion treated with microcurrent (LM, group 4), and lesion treated with combined therapy (LUM, group 5). For groups 3, 4 and 5, treatment was initiated 24 hours after surgery under anesthesia and each group was allocated into three different subgroups $(n=5)$ to allow for the use of the different therapy resources at on days 3, 7 and 14 Photoplanimetry was performed daily. After euthanasia, blood was collected for immune analysis. Results: Ultrasound increased the phagocytic capacity and the production of nitric oxide by macrophages and induced the reduction of CD $4^{+}$cells, the $\mathrm{CD}^{+} / \mathrm{CD}^{+}$ratio, and the plasma concentration of IL-1 $\beta$. Microcurrent and combined therapy decreased the production of superoxide anion, nitric oxide, $\mathrm{CD} 4^{+}$-positive cells, the $\mathrm{CD} 4^{+} / \mathrm{CD}^{+}$ratio, and IL- $1 \beta$ concentration. Conclusions: Therapeutic high-frequency ultrasound, microcurrent, and combined therapy changed the activity of the innate and adaptive immune system during healing process but did not accelerate the closure of the wound.
\end{abstract}

Keywords: wound healing; ultrasonic therapy; electric stimulation therapy; physical therapy specialty.

\section{BULLET POINTS}

- Ultrasound therapy and microcurrent changed the activity of the innate and adaptive immune system.

- Combined therapy further accelerated the response of the adaptive immune system.

- Ultrasound, microcurrent, and combined therapy did not accelerate the closure of acute wounds.

\section{HOW TO CITE THIS ARTICLE}

Korelo RIG, Kryczyk M, Garcia C, Naliwaiko K, Fernandes LC. Wound healing treatment by high frequency ultrasound, microcurrent, and combined therapy modifies the immune response in rats. Braz J Phys Ther. 2016 Mar-Apr; 20(2):133-141. http://dx.doi.org/10.1590/bjpt-rbf.2014.0141

\section{Introduction}

Wound healing is a process in which the body tissue repairs itself through the coordinated action of extra- and intracellular events ${ }^{1}$. The wound-healing process leads to a formation of new tissue that is structurally and functionally identical to its previous state $^{2}$. Biomarkers of inflammation can be monitored, and their persistence in the blood has been associated with disturbances in the healing process. This source of the inflammation has been attributed to macrophages ${ }^{3}$.
Macrophages are cells from the innate immune system that phagocytose and kill pathogenic organisms ${ }^{2}$; they also produce proinflammatory cytokines (e.g.tumor necrosis factor [TNF]- $\alpha$, interleukin [IL]-1 $\beta$, and IL-6) and chemically reactive oxygen and nitrogen molecules. Forty eight hours after tissue injury, macrophages also release IL-10, an anti-inflammatory cytokine which initiates the remodeling of tissues in conjunction with growth factors ${ }^{4}$. Following the

\footnotetext{
${ }^{1}$ Programa de Pós-graduação em Educação Física, Coordenação do Curso de Fisioterapia, Universidade Federal do Paraná (UFPR), Curitiba, PR, Brazil ${ }^{2}$ Faculdade Dom Bosco, Curitiba, PR, Brazil

${ }^{3}$ Departamento de Biologia, UFPR, Curitiba, PR, Brazil

${ }^{4}$ Programa de Pós-graduação em Educação Física, Departamento de Fisiologia, UFPR, Curitiba, PR, Brazil

Received: Dec. 24, 2014 Revised: June 03, 2015 Accepted: Sept. 11, 2015
} 
migration of macrophages to injured tissue, subsets of lymphocytes do the same. For example, $\mathrm{CD}^{+} \mathrm{T}$ lymphocytes are anti-inflammatory while $\mathrm{CD} 8^{+} \mathrm{T}$ lymphocytes are proinflammatory, and the $\mathrm{CD}^{+} / \mathrm{CD}^{+}$ ratio is reduced as the healing process progresses ${ }^{5}$.

The management of wound preparation must follow the principle of tissue infection moisture edge (TIME), meaning that the microenvironment must be maintained to support conditions favorable to the healing process ${ }^{6}$. For the treatment of wounds, non-focused high-frequency ultrasound (HFU) $)^{7-11}$ and microcurrent electrical stimulation (MET) ${ }^{12-18}$ have been used as adjuvant therapies for wound healing. Several studies have reported the positive effects of these approaches based on different mechanisms $\mathrm{s}^{7,8,10,12,15,16,18}$ in the wound-healing process. However, the effects of HFU and MET on the immune system are not fully known, particularly in terms of macrophages and subsets of lymphocyte cells.

The combination of these two therapeutic modalities could amplify the effect of one modality alone. Combined therapy in the context of this paper consists of the therapeutic application of an electrical current through the ultrasonic transducer, providing sound pulses and electrical current flow simultaneously. This association saves time in the application and it is believed that the ultrasound increases the permeability of cell membranes, favoring the action of electrical currents on the nervous tissue ${ }^{19}$. However, research is scarce on the benefits of this synergy, and to the authors knowledge, the combined therapy of the two modalities has not been studied in relation to its effect on wound healing. Therefore, it was hypothesized that the use of physical therapy modalities (i.e. HFU and MET) applied alone would promote beneficial changes in the activities of the innate and adaptive immune system, and that the combined therapy would result in further acceleration of the wound-healing process over that which was believed to occur when each modality was applied as a treatment in isolation.

In this study, the effects of HFU, MET, and combined therapy on wound area, peritoneal macrophage function, lymphocyte immune functions, and the plasma concentration of ILs were investigated.

\section{Method}

\section{Animal model}

A total of 65 male Wistar rats were used (7 weeks old, weighing about $312.7 \mathrm{~g}$, standard error of the mean $[\mathrm{SEM}]=11.6 \mathrm{~g}$ ). The rats were kept in an environment that had a constant temperature $\left(23 \pm 1^{\circ} \mathrm{C}\right)$ under a light/dark cycle (12/12 h), with free access to food and water. This study followed the ethical rules established by Brazilian Law 11.794/08 and the recommendations of the Brazilian College of Animal Experimentation, Moreover, it was approved by the Animal Research Ethics Committee of the Universidade Federal do Paraná (CEUA-UFPR), Curitiba, Paraná, Brazil (protocol number: 561/2012).

\section{Experimental design}

The animals $(n=65)$ were randomly allocated into five groups as follows: control (C, group $1, n=5)$, lesion and no treatment (L, group 2, $\mathrm{n}=15$ ), lesion treated with ultrasound therapy (LU, group $3, n=15$ ), lesion treated with microcurrent therapy (LM, group $4, \mathrm{n}=15$ ), and lesion treated with combined therapy (LUM, group 5, $\mathrm{n}=15$ ). With the exception of the control group, all groups were subdivided into three subgroups ( $\mathrm{n}=5$ each) according to the number of days of treatment. The treatment was conducted once a day everyday until exsanguinated at 3, 7, and 14 days of treatment. The euthanasia of animals was carried out by decapitation following the ethical rules of the Resolution of the CFMV (Federal Board of Veterinary Medicine) number 1000/12. Two animals of group 2 were lost - during the surgical procedure to inflict the original injury. In order to solve this drawback these two animals were replaced at the time of surgery.

\section{Surgical procedure}

The rats were anesthetized with xylazine $(0.05 \mathrm{~mL}$, $10 \mathrm{mg} / \mathrm{mL}, \mathrm{IM} /$ intramuscular $)$ and ketamine $(0.15 \mathrm{~mL}$, $50 \mathrm{mg} / \mathrm{mL}, \mathrm{IM})$ diluted in $9 \%$ potassium chloride $(0.25 \mathrm{~mL})$. After the hair was removed from the back of each rat, the surgical procedure was carried out in which an area of skin was excised by one of the investigators (Figure 1), as described in details elsewhere ${ }^{20}$. After creating the wound, the lesion was cleaned with sterile gauze soaked in saline and received a primary cover (circular self-adhesive dressing of $1.5 \mathrm{~cm}$ ) maintained for 4 hours after the excision. The animals were kept at room temperature under a warm heating pad to prevent hypothermia until full recovery. The animals were then kept in the room noted above and were allowed to have social interaction with the other four animals of the same subgroup.

\section{Treatment protocol}

The treatment was initiated 24 hours after surgery (Figure 2) and carried out once a day everyday, following the schedule ( 3,7 , or 14 days), before 

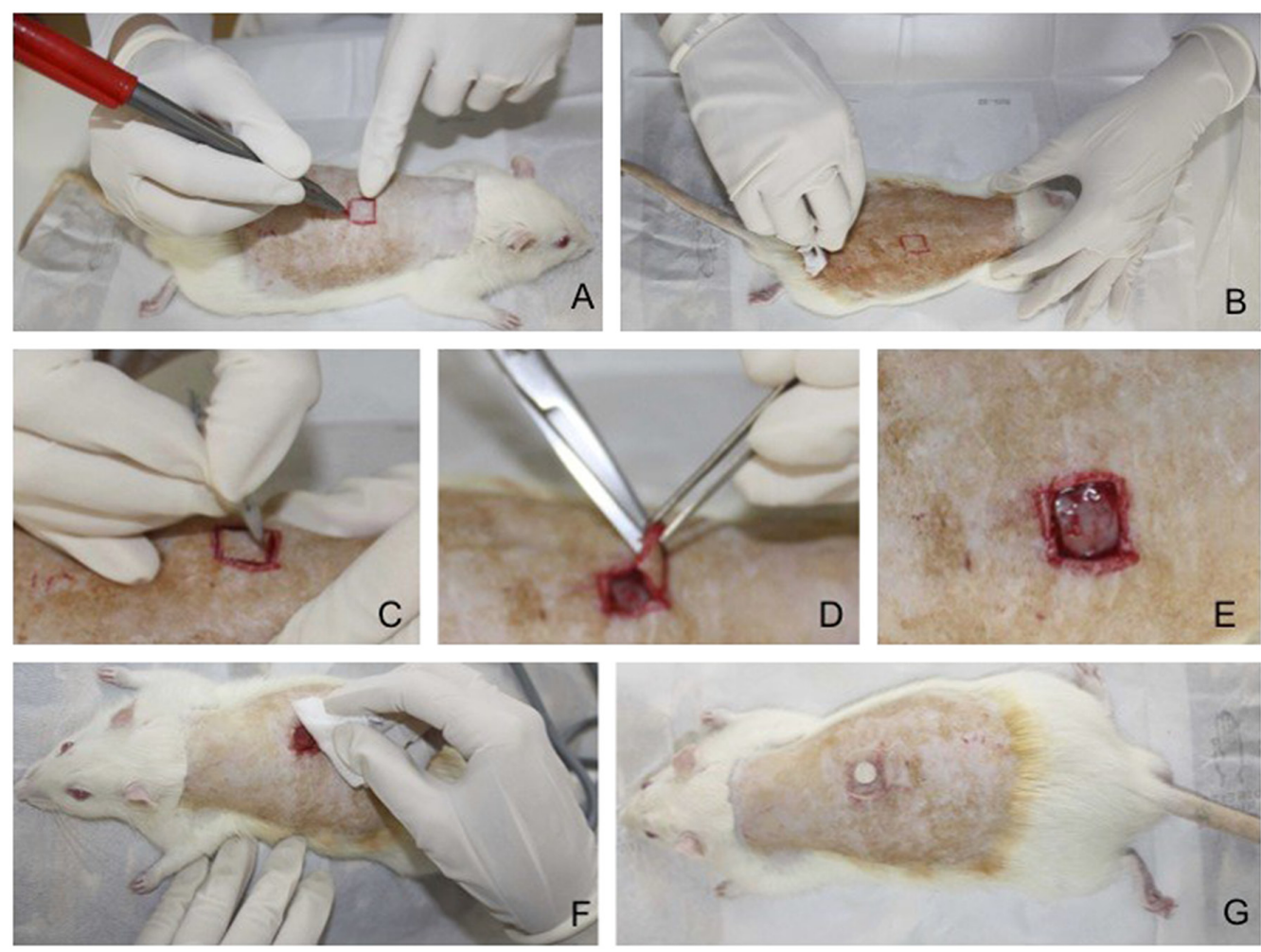

Figure 1. Surgical procedure for creating the lesion. (A) After hair removal, skin-marking excision wound with plastic mold of $1 \mathrm{~cm}^{2}$ to mark the skin, located on the dorsal medial line of the animal, using $1 \mathrm{~cm}$ below the transverse line connecting the lower angle of the scapula as the cranial limit. (B) Asepsis with topical povidone-iodine. (C) Incision with a scalpel blade around the marked tissue. (D) Dissection of the excised skin in the suprafascial plane with tweezers and Mayo scissors, respecting the muscular fascia (2 mm deep). (E) Resection of the skin segment demarcated. (F) Cleaning of excision wound with sterile gauze soaked in saline solution. (G) Primary coverage placement with self-adhesive dressing.
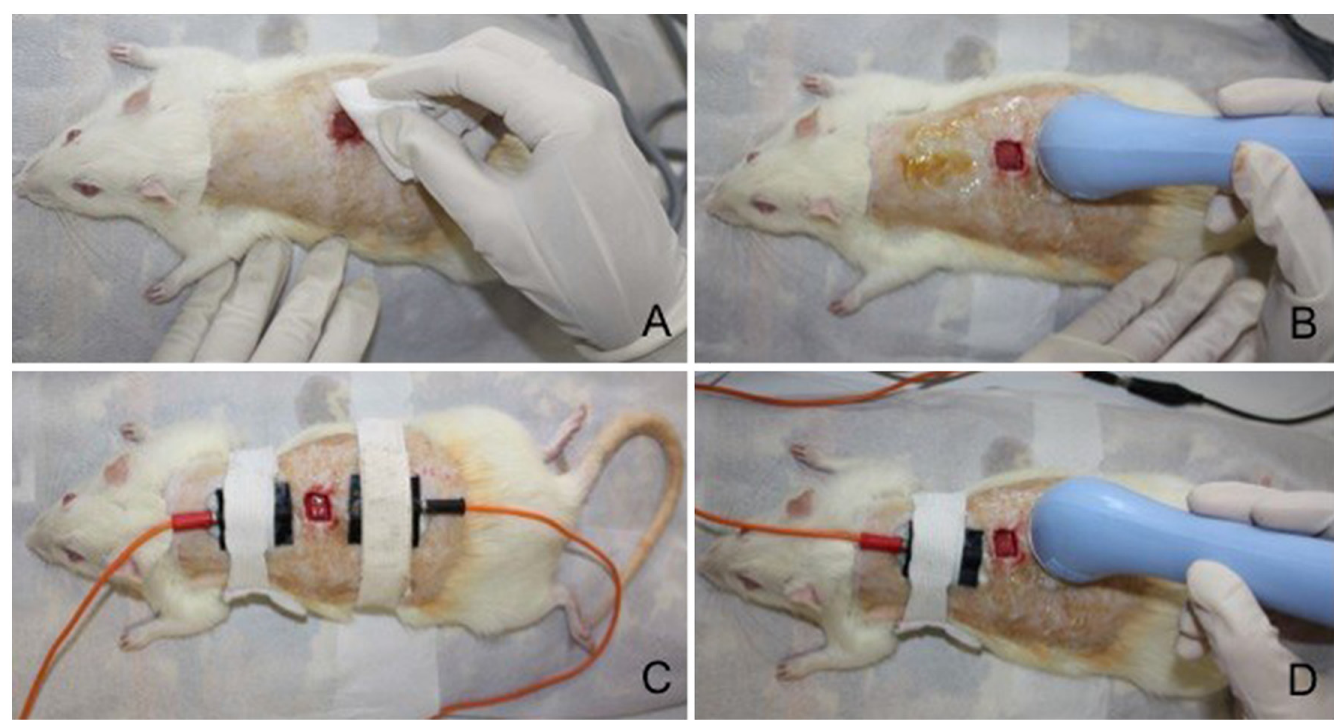

Figure 2. Intervention procedures in the different groups. (A) Cleaning the wound with sterile gauze and saline solution made for the L group (lesion with no treatment group) and prior to the application of the other three forms of intervention. (B) Application of therapeutic ultrasound in animals from the LU group (lesion treated with ultrasound group). (C) Application of microcurrent in animals from the LM group (lesion treated with microcurrent group). (D) Application of combined therapy in animals from the LUM group (lesion treated with ultrasound and microcurrent group). 
euthanasia of animals. With the exception of the control group, all groups had their wounds cleaned daily, under anesthesia, prior to the application of the therapeutic resources. This was done with sterile gauze soaked in saline, and primary coverage was not returned after cleaning. The equipment used underwent assessment and received calibration certification. For the dosage, each parameter was chosen based on previous scientific evidence ${ }^{8,13,17}$. For the LU group (group 3), the HFU (Sonopulse III ${ }^{\circledR}$ IBRAMED portable equipment) was set using a transducer at $3 \mathrm{MHz}$ with the following parameters: effective radiating contact area of $3.5 \mathrm{~cm}^{2}$; pulsed mode $(100 \mathrm{~Hz}) ; 50 \%$ duty cycle; spatial and temporal average intensity of $1.0 \mathrm{~W} / \mathrm{cm}^{2}$ and $0.5 \mathrm{~W} / \mathrm{cm}^{2}$, respectively; and therapeutic dose of $33.6 \mathrm{~J} / \mathrm{cm}^{2}$. The therapy was carried out for 8 minutes via direct contact with water soluble gel around the wound area $\left(25 \mathrm{~cm}^{2}\right)$. For the LM group (group 4), a Neurodyn Esthetic ${ }^{\circledR}$ IBRAMED was used to deliver MET. Conductive silicone electrodes $(30 \mathrm{~mm} \times 50 \mathrm{~mm})$ with water soluble gel were wrapped around the wound and the following parameters were used: intensity $300 \mu \mathrm{A}$, pulse frequency $100 \mathrm{~Hz}$, monophasic rectangular pulse with polarity inversion at every 3 seconds, performed for 8 minutes. For the LUM group (group 5), the two modalities were interconnected using a cable specifically so that the ultrasonic transducer could apply both the sound and electrical pulse. Both modalities were parameterized and the procedures were the same as those described for the LU \& LM groups (groups 3 $\& 4)$; the application was carried out with a static silicon-carbon electrode positioned at the cranial edge of the lesion. The ultrasonic transducer applied by direct contact by manual sliding the transducer around the free borders of the wound.

\section{Percentage reduction of wound area-photoplanimetry}

Wound contraction was evaluated daily until 14 days after surgery and therapies by photographic documentation. For standardization of images, a fixation system was used for the camera with the distance set at $15 \mathrm{~cm}$; the light was controlled using two cold lamps with a power of $45 \mathrm{~W}$. Evaluation wound contraction was analyzed by measuring the area of wound (transition of regular scar tissue skin on the photo), calculated using ImageJ software $1.47 \mathrm{t}^{15}$, calibrated by the caliper used adjacent to the edge of wound ${ }^{13}$, and expressed in percentage. The percentage reduction in the area of the wound was calculated using the following formula ${ }^{21}$ :
Percentage reduction of wound area $(\%)=\frac{(\text { Initial }- \text { Final wound area }) \times 100}{\text { Initial wound area }}$

\section{Interleukin plasma concentration}

The measurements of IL-1 $1 \beta, 6$, and 10 and TNF- $\alpha$ in the plasma were performed following the instructions of the ELISA kit manufacturer (Boster Immunoleader ${ }^{\circledR}$ ).

\section{Macrophage immune parameters}

Resident macrophages were obtained by intraperitoneal lavage from the groups treated for 14 days to verify the functional parameters. Phagocytic capacity, neutral red retention, superoxide anion, hydrogen peroxide $\left(\mathrm{H}_{2} \mathrm{O}_{2}\right)$, and nitric oxide (NO) production were performed in quadruplicate as described elsewhere ${ }^{22}$.

\section{T lymphocyte subpopulations $\mathrm{CD4}^{+} / \mathrm{CD8}^{+}$}

Flow cytometry was used to measure the presence of $\mathrm{CD}^{+}$and $\mathrm{CD}^{+}$, markers of helper and cytotoxic $\mathrm{T}$ lymphocytes, respectively, on the surface of freshly prepared blood lymphocytes, as has been described elsewhere ${ }^{23}$. About $10^{6}$ cells $/ \mathrm{mL}$ in phosphate buffered solution (PBS) supplemented with $0.1 \%$ fetal bovine serum $(\mathrm{wt} / \mathrm{v})$ and $0.05 \%$ sodium azide $(\mathrm{wt} / \mathrm{v})$ were incubated for $20 \mathrm{~min}$ at $4{ }^{\circ} \mathrm{C}$ in the dark with fluorescently labeled monoclonal antibodies to $\mathrm{CD}^{+}$(clone $\mathrm{OX}-38$ ) and $\mathrm{CD}^{+}$(clone $\mathrm{OX}-8$ ). After staining, cells were washed twice with PBS and immediately examined for fluorescence using a Becton Dickinson FACSCalibur.

\section{Statistical analysis}

Data are presented as mean \pm SEM and were subjected to normal analysis and homogeneity of variance using the Shapiro-Wilk test and Levene's test, respectively. For analysis of the percentage reduction in wound area, analysis of variance (ANOVA) with repeated mixed measures was used following a design 2 (reduction of percentage wound area: pre vs. post intervention) $\times 4$ (treatment: lesion vs. ultrasound vs. microcurrent vs. combined therapy) $\times 3$ (time: 3 days vs. 7 days vs. 14 days), with a significance level of $\mathrm{p}<0.05$. For the other variables (IL plasma concentration, functional parameters of macrophage and lymphocyte subpopulations), two-way ANOVA between groups was used. Post hoc tests with Bonferroni's correction were employed for multiple comparisons, with a statistical significance of $p<0.05$. The effect size was determined by calculating omega as follows: $\omega=0.01$ was considered a small effect, $\omega=0.06$ was considered 
an average effect, and values of $\omega$ above 0.14 were considered a large effect. Analyses were performed with IBM-SPSS software version 19 and the graphics prepared with GraphPad PRISM ${ }^{\circledR}$ software version 5.0 for Windows.

\section{Results}

\section{Percentage reduction of wound area}

There was a significant reduction in the wound area pre- and post-therapy intervention (Wilks's lambda $=0.042, \mathrm{~F}_{1,47}=1076.7, \mathrm{p}=0.00$, partial eta squared $=0.958$ ). In addition, there was a positive interaction between time (3, 7 and 14 days) and pre-and post-intervention in the reduction of wound area (Wilks's lambda $=0.096, \mathrm{~F}_{2,47}=221.1, \mathrm{p}=0.00$, partial eta squared $=0.904$ ). There was no significant interaction between the type of treatment and the percentage reduction in wound area pre- and post-intervention (Wilks's lambda $=0.881, \mathrm{~F}_{3,47}=2.118, \mathrm{p}=0.12$, partial eta squared $=0.119$ ). Finally, no significant interaction was observed between the types of treatment for percentage reduction in wound area pre- and post-intervention at different times (Wilks's lambda $=0.882, \mathrm{~F}_{6,47}=1.047$, $\mathrm{p}=0.41$, partial eta squared $=0.118$ ).

\section{Interleukin concentrations}

After 3 days (Table 1), only IL-1 $\beta$ was significantly increased ( $\mathrm{p}=0.04 \mathrm{vs}$. C). The interventions in all three treatment groups (i.e.LU, LM, LUM [groups 3, 4 \& 5]) induced a marked reduction in IL- $1 \beta(\mathrm{p}=0.04, \mathrm{p}=0.02$, and $p=0.04$, respectively vs. L). HFU therapy induced a twofold increase in the concentration of IL- 6 when compared to the control group (group 1) $(\mathrm{p}=0.04)$. At days 7 and 14, the concentration of such cytokines was undetectable.

\section{Macrophage immune parameters}

Table 2 shows the functional parameters of peritoneal macrophages and lymphocytes after surgery at 14 days of therapy. Phagocytosis and neutral red uptake were different between groups $\left(\mathrm{F}_{4,39}=4.095, \mathrm{p}=0.03, \omega=0.22\right.$ and $\mathrm{F}_{4,39}=7.390, \mathrm{p}=0.00, \omega=0.38$, respectively). Phagocytosis and neutral red uptake in the L group (group 2) were reduced by $47 \%$ ( $\mathrm{p}=0.03$ vs. C) and $22.5 \%$ ( $\mathrm{p}=0.08$ vs. C), respectively. The HFU treatment

Table 1. Plasma concentration of interleukin (IL)-1 $\beta$, IL-6, IL-10, and tumor necrosis factor (TNF)- $\alpha$ for the experimental period of 3 days after the excision wound model between the different intervention groups ( $\mathrm{n}=5$ for each group; $\mathrm{C}$ : control; L: lesion without treatment; LU: lesion treated with ultrasound; LM: lesion treated with microcurrent; LUM: lesion treated with combined therapy). The data represent the mean (minimum - maximum), expressed as $\mathrm{pg} / \mathrm{mL}$. Each experiment was performed in triplicate.

\begin{tabular}{cccccc}
\hline & $\mathbf{C}$ & $\mathbf{L}$ & $\mathbf{L U}$ & $\mathbf{L M}$ & $\mathbf{L U M}$ \\
IL-1 $\beta$ & nd & $45(27-64)^{\mathrm{a}}$ & $2.6(0-37)^{\mathrm{b}}$ & $\mathrm{nd}^{\mathrm{b}}$ & $13(6-52)^{\mathrm{b}}$ \\
TNF- $\boldsymbol{\alpha}$ & nd & nd & nd & nd & nd \\
IL-6 & nd & $3.2(0.2-6.1)$ & $8.9(3.5-11)^{\mathrm{a}}$ & $1.2(0.1-5.1)$ & $\mathrm{nd}^{\mathrm{c}}$ \\
IL-10 & nd & nd & nd & nd & nd \\
\hline
\end{tabular}

${ }^{\mathrm{a}} \mathrm{p}<0.05$ compared to $\mathrm{C}$; ${ }^{\mathrm{b}} \mathrm{p}<0.05$ compared to $\mathrm{L}$; ${ }^{\mathrm{c}} \mathrm{p}<0.05$ compared to LU; nd (not detectable).

Table 2. Functional parameters from peritoneal macrophages and blood $\mathrm{CD} 4^{+}$and $\mathrm{CD} 8^{+} \mathrm{T}$ lymphocytes 14 days after excision in the groups ( $\mathrm{n}=5$ for each group; $\mathrm{C}$ : control; L: lesion with no treatment; LU: lesion treated with ultrasound; LM: lesion treated with microcurrent; LUM: lesion treated with combined therapy). Macrophage data represent mean $\pm \mathrm{SEM}$, expressed as absorbance $/ 10^{6}$ cells. Experiment was performed in octuplicate. Data from lymphocytes are expressed as percentage and the experiments were performed in duplicate.

\begin{tabular}{|c|c|c|c|c|c|}
\hline & $\mathrm{C}$ & $\mathbf{L}$ & $\mathbf{L U}$ & $\mathbf{L M}$ & $\mathbf{L U M}$ \\
\hline $\begin{array}{l}\text { Macrophages } \\
\text { Phagocytic capacity }\end{array}$ & $1.91 \pm 0.21$ & $1.0 \pm 0.20^{\mathrm{a}}$ & $1.9 \pm 0.28^{b}$ & $1.74 \pm 0.35$ & $1.58 \pm 0.24$ \\
\hline Red retention & $0.40 \pm 0.02$ & $0.31 \pm 0.01^{\mathrm{a}}$ & $0.32 \pm 0.01$ & $0.26 \pm 0.01^{\mathrm{a}}$ & $0.29 \pm 0.01^{\mathrm{a}}$ \\
\hline Superoxide anion & $2.56 \pm 0.19$ & $2.12 \pm 0.15$ & $1.71 \pm 0.16^{\mathrm{a}}$ & $1.41 \pm 0.75^{\mathrm{a}, \mathrm{b}}$ & $1.44 \pm 0.15^{\mathrm{a}, \mathrm{b}}$ \\
\hline Hydrogen peroxide & $1.60 \pm 0.07$ & $0.93 \pm 0.06^{\mathrm{a}}$ & $0.85 \pm 0.03^{\mathrm{a}}$ & $1.09 \pm 0.08^{\mathrm{a}}$ & $0.82 \pm 0.03^{\mathrm{a}, \mathrm{c}}$ \\
\hline Lymphocytes T CD4 ${ }^{+}$ & $21.2 \pm 0.4$ & $22.6 \pm 0.2^{\mathrm{a}}$ & $19.0 \pm 0.2^{\mathrm{a}, \mathrm{b}}$ & $19.4 \pm 0.3^{\mathrm{a}, \mathrm{b}}$ & $12.0 \pm 1.9^{\mathrm{a}, \mathrm{b}, \mathrm{c}, \mathrm{d}}$ \\
\hline $\mathrm{T} \mathrm{CD}^{+}$ & $19.0 \pm 0.2$ & $14.9 \pm 0.3^{\mathrm{a}}$ & $19.0 \pm 1.9$ & $20.3 \pm 0.8^{b}$ & $17.6 \pm 5.8$ \\
\hline $\mathrm{TCD}^{+} / \mathrm{CD}^{+}$ & $1.1 \pm 0.04$ & $1.5 \pm 0.01^{\mathrm{a}}$ & $1.0 \pm 0.11^{\mathrm{b}}$ & $0.9 \pm 0.05^{\mathrm{b}}$ & $0.8 \pm 0.17^{\mathrm{b}}$ \\
\hline
\end{tabular}

${ }^{\mathrm{a}} \mathrm{p}<0.05$ compared to $\mathrm{C} ;{ }^{\mathrm{b}} \mathrm{p}<0.05$ compared to $\mathrm{L} ;{ }^{\mathrm{c}} \mathrm{p}<0.05$ compared to LU; ${ }^{\mathrm{d}} \mathrm{p}<0.05$ compared to LM. 
(LU group) [group 3] showed only the recovery of phagocytosis capacity ( $\mathrm{p}=0.04$ vs. the lesion without treatment group (group 2)). Neither microcurrent therapy (group 4) nor combined therapy (group 5) reversed the effect caused by excision ( $\mathrm{p}>0.05)$. Superoxide and hydrogen peroxide production were different between groups $\left(\mathrm{F}_{4,39}=9.807, \mathrm{p}=0.00, \omega=0.46\right.$ and $\mathrm{F}_{4,39}=25.786, \mathrm{p}=0.00, \omega=0.78$, respectively). Superoxide production did reduce in group 2 (lesion without treatment group) but was not different from the control group $(\mathrm{p}=0.56)$ [group 1]. HFU therapy (group 3) caused a further reduction in superoxide production but the reduction was not different from the lesion without treatment group $(\mathrm{p}=0.72)$ [group 2]. In contrast, the microcurrent therapy (group 4) and combined therapy (LUM) (group 5) caused a significant reduction ( $\mathrm{p}<0.05 \mathrm{vs}$. group 2$)$ in the superoxide production (33\%) when compared to the Lesion without treatment group (group 2). For hydrogen peroxide, the lesion without treatment group (group 2) showed a reduction of $\mathrm{H}_{2} \mathrm{O}_{2}$ production of $42 \%$ ( $\mathrm{p}=0.00$ vs. the control group (group 1)). The different modalities (groups 3, 4, \& 5) did not modify the $\mathrm{H}_{2} \mathrm{O}_{2}$ production when compared to the Lesion without treatment group (p>0.05) (group 2).

The production of NO is shown in Figure 3. This was different between groups $\left(\mathrm{F}_{4,39}=15.451, \mathrm{p}=0.00\right.$, $\omega=0.74)$. The basal concentration of NO production

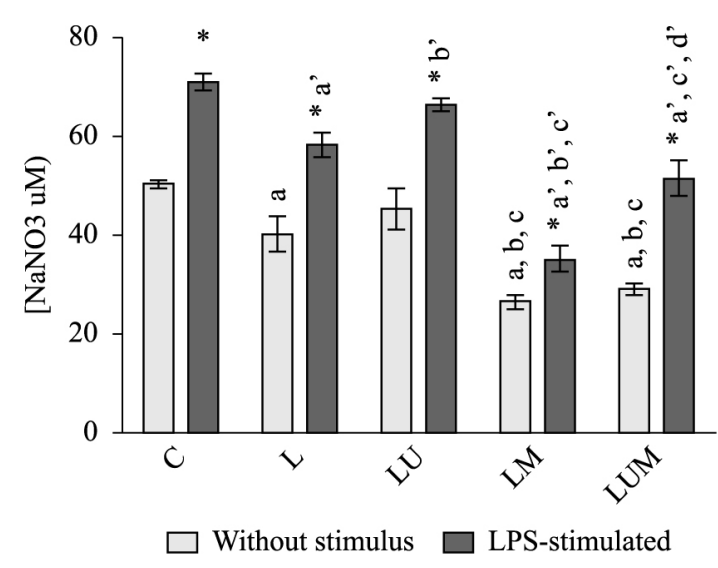

Figure 3. Nitric oxide production by peritoneal macrophages 14 days after excision model without stimulus and LPS-stimulated in the groups (C: control; L: lesion with no treatment; LU: lesion treated with ultrasound; LM: lesion treated with microcurrent; LUM: lesion treated with combined therapy). The data represent the mean $\pm \mathrm{SEM}$, expressed as $\mu \mathrm{mol} / \mathrm{L}$. Each experiment was performed in quadruplicate. ${ }^{*} \mathrm{p}<0.05$ relative to its respective group; ${ }^{\mathrm{a}} \mathrm{p}<0.05$ compared to $\mathrm{C}$; ${ }^{b} \mathrm{p}<0.05$ compared to $\mathrm{L} ;{ }^{\mathrm{c}} \mathrm{p}<0.05$ compared to $\mathrm{LU}$; ${ }^{\mathrm{d}} \mathrm{p}<0.05$ compared to LM. by peritoneal macrophages was reduced in the lesion without treatment group (group 2) $(\mathrm{p}=0.04$ vs. the control group (group 1)). HFU therapy (group 3) did reverse the effect of the lesion ( $\mathrm{p}=0.39$ vs. the control group [group 1]). In contrast, for the microcurrent therapy alone group (LM group or group 4) and in combination with the HFU (the LUM group or group 5), the production was about $50 \%$ of the basal state. Under lipopolysaccharide (LPS) stimulation, it was also statistical different between the groups $\left(\mathrm{F}_{4,19}=30.875, \mathrm{p}=0.00, \omega=0.85\right)$. Under LPS stimulation, peritoneal macrophages increased in about $30 \%$ from control ( $\mathrm{p}=0.00 v s$ non-stimulated). The same was seen in the L (group 2) and LU (group 3) groups ( $p<0.01$ vs. non-stimulated). In the LM group (group 4), LPS stimulation increased the nitric oxide production by $\sim 20 \%$ ( $\mathrm{p}=0.02 \mathrm{vs}$. non-stimulated). In the presence of LPS, the combined therapy (group 5) increased the NO production by $\sim 40 \%(\mathrm{p}<0.01 v s$. non-stimulated $)$.

\section{T lymphocyte subpopulations $\mathrm{CD}^{+} / \mathrm{CD8}^{+}$}

The excised lesion (group 2) increased (Table 2) the $\mathrm{CD}^{+} \mathrm{T}$ lymphocyte subset (6.19\%) as compared to control group (group 1) $(\mathrm{p}=0.03)$. The therapy with HFU (group 3) or microcurrent (group 4) significantly decreased $(\sim 15 \%)$ the population of $\mathrm{CD}^{+} \mathrm{T}$ lymphocytes when compared to the Control (group 1) and L (group 2) groups ( $\mathrm{p}=0.02$ and $\mathrm{p}=0.04$, respectively). The combined therapy (group 5) showed an even further reduction $45 \%$; ( $\mathrm{p}=0.04 \mathrm{vs}$. control (group 1), $\mathrm{p}=0.03$ vs. lesion without treatment (group 2), $\mathrm{p}=0.02$ vs. LU (group 3 ) and $\mathrm{p}=0.02$ vs. LM (group 4)). $\mathrm{CD}^{+} \mathrm{T}$ lymphocytes in the lesion group (group 2) was reduced by $22 \%$ ( $\mathrm{p}=0.02$ vs. control group (group 1)). The different therapies (groups $3 \& 4$ ) and their combination (group 5) recovered the CD8+ T lymphocyte population to control levels ( $\mathrm{p}>0.05$ vs. control group (group 1)). The $\mathrm{CD}^{+} / \mathrm{CD}^{+}$ratio increased in the lesion group (group 2) ( $\mathrm{p}=0.03$ vs. control group (group 1)). The different therapies (groups $3 \& 4$ ) and their combination (group 5) reversed the effects caused by the excision lesion to control level ( $p=0.04$ vs. LU (group 3 ), $p=0.03$ vs. LM (group 4), $\mathrm{p}=0.02$ vs. LUM (group 5)).

\section{Discussion}

In this study, the effect of HFU, microcurrent, and combined therapies on the immune system and healing process in a wound-induced excision model was investigated. Contrary to the findings of this 
study, other studies have shown acceleration of the wound-healing process with $\mathrm{HFU}^{8,10,20}$ and $\mathrm{MET}^{12,16}$; however, this previous research did not explore the immune system as was done in the present study. Inflammation is a key factor in the healing process, followed by cell proliferation and maturation ${ }^{2-4}$. Our results showed that the two different physical therapy modalities were able to significantly modulate macrophages immune parameters, decrease the expression of pro-inflammatory cytokines, and decrease the expression of $\mathrm{CD}^{+}$-positive cells in association with a reduced $\mathrm{CD} 4^{+} / \mathrm{CD} 8^{+}$ratio. In addition, the combination of both modalities (combined therapy) further decreased the expression of $\mathrm{CD}^{+}$-positive cells and the $\mathrm{CD}^{+} / \mathrm{CD}^{+}$ratio. These changes, which were brought about by the combined therapy, suggest that the rats immune system was attempting to solve the healing process. However, although the different approaches resulted in a significant reduction in the wound area, their use for this purpose was not supported, as there was no statistically significant difference compared to untreated excised lesions.

Because these therapies were able to change the immune parameters, helping to modulate the healing process, and given the fine line of percentage change between the different interventions, a change in wound area would also be expected. However, the present study did not detect such a result. This result might have been affected by the dosage parameters of the modalities used, although based on previous evidence $^{8,13,17}$, the dosage used in this study was not enough to promote the acceleration of wound healing. It must be pointed out that in the present study, only a specific dosages were evaluated; thus, the results cannot be extrapolated to conditions in which other parameters and/or different forms of electrical stimulation may be used. Further research is needed to determine the ideal dose-response treatment for the different stages of wound healing.

It has been shown ${ }^{24}$ that different doses of HFU and microcurrents increase the tensile strength of tissue being repaired, which is important for tissue quality. As a matter of fact, the cytokine network is important for tissue quality ${ }^{2,4}$; the present study showed that different physical therapy modalities are able to alter the plasma concentrations of ILs.

HFU reduced the concentration of IL- $1 \beta$ (known as pro-inflammatory) along with an increase in IL-6 (in the early phase of inflammation, this is a chemoattractant cytokine for keratinocytes) 3 days after the lesion was generated. This was seen with both modalities for
IL- $1 \beta$ concentration. The concentrations of IL- 6 and TNF- $\alpha$ increased markedly and IL- $1 \beta$ and IL- 10 were observed in lower amounts ${ }^{24}$. The methods used in this study somehow contributed to the delicate balance between these cytokines, attenuating the inflammatory response because IL- $1 \beta$ is a potent inducer of the transduction signaling cascade for growth factors involved in the migration of inflammatory cells and the production of prostaglandins for nociception ${ }^{25}$.

An in vitro ${ }^{26}$ study showed that HFU therapy stimulated the release of IL- $1 \beta$ at a low rate due to three possible mechanisms: an increase in cell membrane permeability; changes in the signal transduction that regulated gene expression; and alterations in the cytoskeleton, affecting cell metabolism and gene expression. However, the precise mechanism is still unknown. The reduction of IL-1 $\beta$ by the microcurrent therapy may have lead to the possible involvement of nuclear factor $\kappa \mathrm{B}(\mathrm{NF} \kappa \mathrm{B})$ and mitogen-activated protein kinase (MAPK) ${ }^{27}$.

Fourteen days after wound-induced excision, HFU increased the phagocytosis capacity and the NO production in the presence of the challenger LPS. The authors are not aware of any study that investigated the innate immune system following physical therapy treatment and the authors hypothesize that this increase was due to the capacity of the ultrasound therapy to induce a stable cavitation related to the transitory increment of cell permeability to calcium influx ${ }^{7,11}$. Along with increased phagocytic capacity, HFU also increased NO production in the presence of LPS at the same level of control group. This increase may have been caused by higher intracellular calcium concentration $^{28,29}$, revealing its antioxidant potential and resulted in low levels of the other two redox molecules (i.e. superoxide anion and $\mathrm{H}_{2} \mathrm{O}_{2}$ ). Indeed, the formation of redox by ultrasound is related to the sonolysis of water generated by the cavitation ${ }^{11}$; however, the acoustic parameters used in the present experiment were insufficient to induce their formation, perhaps because ultrasonic frequencies up to $2 \mathrm{MHz}$ were not able to sonolyze water ${ }^{30}$.

Interestingly, the microcurrent decreased superoxide anion production concurrently with increased production of NO in the presence of LPS, confirming its antimicrobial power, but with lower expression when compared to the lesion without treatment group (group 2). An excess of redox molecules can damage tissues and amplify the pro-inflammatory response, perhaps leading to a chronic stage ${ }^{31}$. Microcurrent therapy increases the adenosine triphosphate (ATP) 
concentration, where ATP acts as an antioxidant to stabilize mitochondrial function ${ }^{32}$. In fact, low-grade NO production at the end of the healing process restores collagen concentration to physiological levels, but the mechanisms for this are not known ${ }^{33}$. Curiously, combined therapy reduced $\mathrm{H}_{2} \mathrm{O}_{2}$, superoxide anion, and NO production. NO production has been proposed as a common mechanism for both therapeutic approaches ${ }^{34}$, however, this still needs to be proven. The present data does not support this suggestion. The authors think that different energy forms-whether mechanical or electrical-trigger a sequence of events to stimulate or inhibit cell processes which leads to the wound-healing process.

Finally, both modalities alone and in combination reduced the $\mathrm{CD} 4^{+} / \mathrm{CD} 8^{+}$ratio, suggesting the resolution of the inflammatory process ${ }^{5}$. The $\mathrm{CD} 8^{+} \mathrm{T}$ cell population was maintained at control levels, resulting in better tissue quality, although this was only applicable to microcurrent therapy because $\mathrm{CD} 4^{+}$cells are considered up-regulatory, leading to the formation of fragile scar tissue and $\mathrm{CD} 8^{+}$down-regulation, which makes the scar tissue more denserigid ${ }^{5}$. In addition, $\mathrm{CD} 8^{+}$cells regulate the production of cytokines through $\mathrm{CD}^{+}$, and consequently, result in a lower level of cytokines ${ }^{5}$. Different organisms with high regenerative capacity (e.g. zebrafish, salamander, and human fetuses) have lower power for stimuli to activate the signaling cascade of the healing process and present with an absence of inflammatory cells at the site of injury, which might be a prerequisite for better repair and tissue quality and/or complete regeneration ${ }^{3}$. This suggests that the modalities used in this study could be useful in modulating the immune system, thereby helping in the formation of a new tissue.

In future studies, the quality of scar tissue should also be measured and local biomarkers should be investigated. In the present study, only circulating markers were measured because the aim of the study was to look at the healing phenomenon from a systemic perspective. The present work sheds light on the therapeutic approaches and the effect of two modalities used alone or together on the immune system. An environment of excessive inflammation may lead to inadequate healing, thereby delaying the healing process and increasing the amount of scar tissue. This means that it might be feasible to manipulate the immune response in the healing process, especially if the patient was willing to sacrifice the wound area reduction rate for a better esthetic result. The physical therapy modalities studied here could contribute to such applications.

\section{Conclusions}

High frequency ultrasound, microcurrent and combining the two modalities were able to modulate the activity of the innate and adaptive immune system, improving the inflammatory environment but not accelerating the wound-healing process. More studies are needed to understand the mechanisms involved in the modulation of wound healing using different physical agents, as well as the relation of these different physical modalities with the quality of the newly formed tissue.

\section{References}

1. Ennis WJ, Sui A, Bartholomew A. Stem cells and healing: impact on inflammation. Adv Wound Care. 2013;2(7):369-78. http://dx.doi.org/10.1089/wound.2013.0449. PMid:24587974.

2. Janis JE, Harrison B. Wound healing: part I. basic science. Plast Reconstr Surg. 2014;133(2):199e-207e. http://dx.doi. org/10.1097/01.prs.0000437224.02985.f9. PMid:24469191.

3. Eming SA, Hammerschmidt M, Krieg T, Roers A. Interrelation of immunity and tissue repair or regeneration. Semin Cell Dev Biol. 2009;20(5):517-27. http://dx.doi.org/10.1016/j. semcdb.2009.04.009. PMid:19393325.

4. Strbo N, Yin N, Stojadinovic O. Innate and adaptive immune responses in wound epithelialization. Adv Wound Care. 2014;3(7):492-501. http://dx.doi.org/10.1089/wound.2012.0435. PMid:25032069.

5. Boyce DE, Jones WD, Ruge F, Harding KG, Moore K. The role of lymphocytes in human dermal wound healing. Br J Dermatol. 2000;143(1):59-65. http://dx.doi.org/10.1046/j.13652133.2000.03591.x. PMid:10886136.

6. Leaper DJ, Schultz G, Carville K, Fletcher J, Swanson T, Drake R. Extending the TIME concept: what have we learned in the past 10 years? Int Wound J. 2012;9(Suppl 2):1-19. http://dx.doi.org/10.1111/j.1742-481X.2012.01097.x. PMid:23145905.

7. Ennis WJ, Lee C, Plummer M, Meneses P. Current status of the use of modalities in wound care: electrical stimulation and ultrasound therapy. Plast Reconstr Surg. 2011;127(Suppl 1):93S-102S. http://dx.doi.org/10.1097/PRS.0b013e3181fbe2fd. PMid:21200278.

8. Taradaj J, Franek A, Brzezinska-Wcislo L, Cierpka L, Dolibog $\mathrm{P}$, Chmielewska D, et al. The use of therapeutic ultrasound in venous leg ulcers: a randomized, controlled clinical trial. Phlebology. 2008;23(4):178-83. http://dx.doi.org/10.1258/ phleb.2008.008015. PMid:18663117.

9. Cullum N, Al-Kurdi D, Bell-Syer SE. Therapeutic ultrasound for venous leg ulcers. Cochrane Database Syst Rev. 2010;6(6):CD001180. http://dx.doi.org/10.1002/14651858. CD001180.pub3. PMid:20556749.

10. Polak A, Franek A, Blaszczak E, Nawrat-Szoltysik A, Taradaj J, Wiercigroch L, et al. A prospective, randomized, controlled, clinical study to evaluate the efficacy of highfrequency ultrasound in the treatment of stage II and stage III pressure ulcers in Geriatric patients. Ostomy Wound Manage. 2014;60(8):16-28. PMid:25105475. 
11. Furusawa Y, Hassan MA, Zhao QL, Ogawa R, Tabuchi Y, Kondo T. Effects of therapeutic ultrasound on the nucleus and genomic DNA. Ultrason Sonochem. 2014;21(6):2061-8. http:// dx.doi.org/10.1016/j.ultsonch.2014.02.028. PMid:24657073.

12. Bayat M, Asgari-Moghadam Z, Maroufi M, Rezaie FS, Bayat M, Rakhshan M. Experimental wound healing using microamperage electrical stimulation in rabbits. J Rehabil Res Dev. 2006;43(2):219-26. http://dx.doi.org/10.1682/ JRRD.2005.05.0089. PMid:16847788.

13. Balakatounis KC, Angoules AG. Low-intensity electrical stimulation in wound healing: review of the efficacy of eternally applied currents resembling the current of injury. Eplasty. 2008;8:283-91. PMid:18552975.

14. Poltawski L, Watson T. Bioelectricity and microcurrent therapy for tissue healing: a narrative review. Phys Ther Rev. 2009;14(2):104-14. http://dx.doi.org/10.1179/174328809X405973.

15. Korelo RIG, Valderramas S, Ternoski B, Medeiros DS, Andres LF, Adolph SMM. Microcurrent application as analgesic treatment in venous ulcer: a pilot study. Rev Lat Am Enfermagem. 2012;20(4):753-60. http://dx.doi. org/10.1590/S0104-11692012000400016. PMid:22990161.

16. Thakral G, LaFontaine J, Najafi B, Talal TK, Kim P, Lavery LA. Electrical stimulation to accelerate wound healing. Diabet Foot Ankle. 2013;4(0). http://dx.doi.org/10.3402/dfa. v4i0.22081. PMid:24049559.

17. Bélanger A-Y. Therapeutic electrophysical agents: evidence behing practice. $3^{\text {rd }}$ ed. Baltimore: Lippincott Williams \& Wilkins; 2014.

18. Torkaman G. Electrical stimulation of wound healing: a review of animals experimental evidence. Adv Wound Care (New Rochelle). 2014;3(2):202-18. http://dx.doi.org/10.1089/ wound.2012.0409. PMid:24761359.

19. Moretti FA, Marcondes FB, Provenza JR, Fukuda TY, Vasconcelos RA, Roizenblatt S. Combined therapy (ultrasound and interferential current) in patients with fibromyalgia: once or twice in a week? Physiother Res Int. 2012;17(3):142-9. http://dx.doi.org/10.1002/pri.525. PMid:22114059.

20. Altomare M, Nascimento AP, Romana-Souza B, Amadeu TP, Monte-Alto-Costa A. Ultrasound accelerates healing of normal wounds but not of ischemic ones. Wound Repair Regen. 2009;17(6):825-31. http://dx.doi.org/10.1111/j.1524475X.2009.00542.x. PMid:19821959.

21. Rijswijk L. Measuring wounds to improve outcomes. Am J Nurs. 2013;113(8):60-1. http://dx.doi.org/10.1097/01. NAJ.0000432967.20419.1b. PMid:23884002.

22. Bonatto SJR, Folador A, Aikawa J, Yamazaki RK, Pizatto $\mathrm{N}$, Oliveira $\mathrm{HH}$, et al. Lifelong exposure to dietary fish oil alters macrophage responses in Walker 256 tumor-bearing rats. Cell Immunol. 2004;231(1-2):56-62. http://dx.doi. org/10.1016/j.cellimm.2004.12.001. PMid:15919370.

23. Jeffery NM, Newsholme EA, Calder PC. Level of polyunsaturated fatty acids and the n- 6 to $n-3$ polyunsaturated fatty acid ratio in the rat diet alter serum lipid levels and lymphocyte functions. Prostaglandins Leukot Essent Fatty Acids. 1997;57(2):149-60. http://dx.doi.org/10.1016/S09523278(97)90005-3. PMid:9250698.

24. Ng GY. Comparing therapeutic ultrasound with microamperage stimulation therapy for improving the strength of Achilles tendon repair. Connect Tissue Res. 2011;52(3):178-82. http:// dx.doi.org/10.3109/03008207.2010.500752. PMid:20672987.

25. Grimstad Ø, Sandanger Ø, Ryan L, Otterdal K, Damaas JK, Pukstad B, et al. Cellular sources and inducers of cytokines presents in acute wound fluid. Wound Repair Regen. 2011;19(3):337-47. http://dx.doi.org/10.1111/j.1524475X.2011.00668.x. PMid:21371163.

26. Doan N, Reher P, Meghji S, Harris M. In vitro effects of therapeutic ultrasound on cell proliferation, protein synthesis, and cytokine production by human fibroblasts, osteoblasts, and monocytes. J Oral Maxillofac Surg. 1999;57(4):409-19, discussion 420. http://dx.doi.org/10.1016/ S0278-2391(99)90281-1. PMid:10199493.

27. Kim JH, Choi H, Suh MJ, Shin JH, Hwang MH, Lee HM. Effect of biphasic electrical current stimulation on IL-1 $\beta$ stimulated annulus fibrosus cells using in vitro microcurrent generating chamber system. Spine (Phila Pa 1976). 2013;38(22):E1368-76. http://dx.doi.org/10.1097/ BRS.0b013e3182a211e3. PMid:23823576.

28. Wink DA, Hines HB, Cheng RY, Switzer CH, Flores-Santana $\mathrm{W}$, Vitek MP, et al. Nitric oxide and redox mechanisms in the immune response. J Leukoc Biol. 2011;89(6):873-91. http://dx.doi.org/10.1189/jlb.1010550. PMid:21233414.

29. Bernatchez SF, Menon V, Stoffel J, Walters SA, Lindroos WE, Crossland MC, et al. Nitric oxide levels in wound fluid may reflect the healing trajectory. Wound Repair Regen. 2013;21(3):410-7. http://dx.doi.org/10.1111/wrr.12048. PMid:23627618.

30. Lifka J, Ondruschka B, Hofmann J. The use of ultrasound for the degradation of pollutants in water: aquasononolysis: a review. Eng Life Sci. 2003;3(6):253-62. http://dx.doi. org/10.1002/elsc.200390040.

31. Guo S, Dipietro LA. Factors affecting wound healing. J Dent Res. 2010;89(3):219-29. http://dx.doi.org/10.1177/0022034509359125. PMid:20139336.

32. Lee BY, Al-Waili N, Stubbs D, Wendell K, Butler G, AlWaili $\mathrm{T}$, et al. Ultra-low microcurrent in the management of diabetes mellitus, hypertension on chronica wounds: report of twelve cases and discussion of mechanism of action. Int J Med Sci. 2009;7(1):29-35. http://dx.doi.org/10.7150/ ijms.7.29. PMid:20046232.

33. Park JE, Abrams MJ, Efron PA, Barbul A. Excessive nitric oxide impairs wound collagen accumulation. J Surg Res. 2013;183(1):487-92. http://dx.doi.org/10.1016/j.jss.2012.11.056. PMid:23290597.

34. Ennis WJ, Lee C, Meneses P. A biochemical approach to wound healing through the use of modalities. Clin Dermatol. 2007;25(1):63-72. http://dx.doi.org/10.1016/j. clindermatol.2006.09.008. PMid:17276203.

\author{
Correspondence \\ Raciele I. Guarda Korelo \\ Universidade Federal do Paraná \\ Coordenação do Curso de Fisioterapia \\ Avenida Coronel Francisco Heráclito dos Santos, 210 \\ CEP 81531-980, Curitiba, PR, Brazil \\ e-mail: raciele@ufpr.br
}

